\title{
DOSSIÊ HISTÓRIA E LITERATURA
}

O dossiê História e Literatura: diálogos e interações apresenta um corpus meditativo cujas reflexões procuram estabelecer pontos de contatos entre a criação ficcional e a realidade histórica nela representada. Não é de hoje que história e literatura andam de mãos dadas, as interações e divergências entre as duas encontram ecos no pensamento ocidental desde a Antiguidade.

Aristóteles talvez tenha sido o primeiro a notar a relevância desta intersecção, conferindo-lhe legitimidade ao reformular a noção de mimese proposta no pensamento platônico. Isto porque a importância atribuída ao poeta na filosofia aristotélica resulta do reconhecimento das experiências humanas no mundo sensível, algo anteriormente negado pelo idealismo platônico. Na Poética de Aristóteles, a imitação ganhou novo status por meio da noção de verossimilhança e da experiência daquele que se relaciona com o objeto artístico, bem como os efeitos sobre ele também adquiriram novos contornos, caso das reflexões acerca da catarse.

E se, no medievo, o controle do que era esteticamente produzido e apreciado, pelos poucos que sabiam ler, também tocava nas questões relacionais entre fiç̧ão e realidade, ao pensar nos problemas que envolvem a criação, por meio da estética, a filosofia moderna continuou a abrir caminhos para se pensar na relação história e literatura. Ao inverter as posições de valorização do objeto para o sujeito, demonstrando que o objeto não é por si só, resultando daquilo que o sujeito pensa dele, a centralidade conferida ao sujeito em relação ao objeto na filosofia kantiana sugere modos novos de se pensar a relação do sujeito com o objeto estético, sujeito e relação que na estética hegeliana devem ser pensados na relação com o contexto.

Apesar da longa trajetória de reflexões envolvendo a relação história e literatura, no livro História, Ficção e Literatura Luiz Costa Lima nos mostra o quanto o assunto ainda carece de reflexões. Ao proceder à análise de Os Sertões de Euclides da Cunha, o teórico da literatura recorre a Roland Barthes e Paul Ricoeur para dar conta de suas concepções sobre o que considera um equívoco: considerar o texto euclidiano simultaneamente de história e de literatura. Entretanto, priorizando as fases estabelecidas por Ricoeur na 
operação histórica, Costa Lima admite a impossibilidade de separar por completo as escritas da história e da ficção, uma vez que não há contradição entre um discurso verdadeiro e o pensamento do que poderia ter ocorrido.

Se, de um ponto de vista teórico, Costa Lima retomou a questão por meio de longas e consistentes reflexões, do ponto de vista do criador da literatura, o escritor Milan Kundera se apresenta como um romancista contemporâneo cuja preocupação com o tema chama a atenção.

Das leituras kunderianas infere-se que história e literatura se encontram no romance como um feixe de luz em que uma é iluminada pela outra. Se a literalidade do texto permite um desembotamento do olhar no sentido de fazer enxergar não uma, mas diversas possibilidades de regimes de verdades, os fatos históricos encontram condições de serem pensados por meio de uma problematização sensível. Por sua vez, no entendimento de Kundera, a história funciona no romance como um feixe de luz que ilumina a vida das personagens - para ele, só na relação com a história é que a existência, objeto primeiro das narrativas literárias, se descortina.

O romancista faz ver que pensar as questões humanas só é possível nas suas relações com a vida vivida por meio de histórias contadas dentro da História. Assim, o pensamento de Kundera dialoga com as intenções deste dossiê, especialmente porque ao mesmo tempo que reconhece as interações entre as duas narrativas, também se mostra reticente em relação a qualquer acordo de subordinação operado no processo interpretativo de uma ou de outra, insistindo, deste modo, no reconhecimento das diferenças e autonomias de uma de outra.

Destarte, a partir da premissa de possibilidades dialogais entre História e Literatura, contidas no artigo Construções de um passado histórico ficcional: uma leitura da trilogia da memória de Pedro Orgambide, Fernanda Palo Prado propõe uma leitura da trilogia da memória do escritor argentino, que, a partir do exílio mexicano, tece uma trama ficcional (re) construindo o passado coletivo de sua pátria. Já o artigo de Michelle Márcia Cobra Torres, História e Literatura: reflexões teóricas, envereda por uma reflexão teórica cujo objetivo é discutir as relações entre as áreas confrontando posições teóricas e ponderando sobre seus pontos de contato e de afastamento. Para estruturar suas reflexões no artigo Manifesto de Utopia: antropofagia e identidade nas reflexões de Oswald de Andrade como 
um intérprete do Brasil, Raíssa Varandas Galvão debruça-se sobre os escritos de Oswald de Andrade, contidos em o Manifesto Antropofágico e no livro de ensaios A Utopia Antropofágica. As leituras têm por finalidade cotejar de ideias ali desenvolvidas para pensá-las como possibilidades de interpretação da sociedade brasileira. Susan sontag Uma intelectual libertária/conservadora/radical nas Américas é o nome do texto no qual Priscila Ribeiro Dorella procura reconstituir o percurso de Susan Sontag, enquanto intelectual e literata comprometida com as questões políticas de seu tempo, destacando especialmente suas relações com intelectuais e escritores consagrados da literatura na América Latina.

As reflexões que perfazem os artigos contidos neste dossiê certamente não esgotam o assunto. Estamos certas de que, além daquelas que insistem em nos incomodar, muitas questões continuarão a ser postas. Contudo, o modo singular, que cada autor escolhe aqui para por o assunto em movimento, traz novas possibilidades de se pensar esta relação tão cara aos estudos das artes e das humanidades no âmbito das pesquisas acadêmicas.

Em época de pandemia, que os espíritos se sensibilizem com as reflexões aqui propostas. Boa leitura a todas e a todos!

Eloísa Pereira Barroso (UnB) \& Maria Veralice Barroso (SEE/DF) 